\title{
Inspiracje twórcze Antoniego Korwina Kossakowskiego
}

\author{
Małgorzata Pawlata*
}

Postać Antoniego Korwina Kossakowskiego nastręcza badaczom literatury wiele trudności. Kłopoty zaczynają się już na etapie odtwarzania biografii poety ${ }^{1}$. Informacje o jego życiu są skromne, a na domiar złego dość fantastyczne i trudne do potwierdzenia. Już współcześni mu nie do końca wierzyli w bajeczne historie, jakie opowiadał na swój temat, co wiemy z Pamiętników Józefa Ignacego Kossakowskiego, biskupa inflanckiego, który w 1764 roku miał okazję go poznać. Biskup pisał:

Znalazłem naówczas w Warszawie nową historią z moim imiennikiem, p. Kossakowskim Antonim [...], że 24 lata był miany za zaginionego; dotąd nawet historia jego awantur nie może mi być pewną, bo kilka razy o niej mówiąc, zawsze mawiał odmiennie, a zatem nie mam wielkiej wiary; to zaś jest jednak pewnem, iż jak uciekł z domu, dostał się do akademii za profesora, nie wiadomo dobrze dla jakiej awantury oddalony został, zostawszy popem, czyli starszym sekty jednej bohomolców, siedział czas niejaki na Wołoszczyźnie i stamtąd rozpisywał do różnych osób listy, oznajmując o sobie, że pod imieniem Moliwdy panuje na jednej wyspie w Grecji ${ }^{2}$.

* Uniwersytet Lódzki, Wydział Filologiczny, Instytut Filologii Polskiej i Logopedii, Pracownia Edytorstwa, 90-236 Lódź, ul. Pomorska 171/173, e-mail: malgorzata.pawlata@uni.lodz.pl.

1 Antoni Korwin Kossakowski herbu Ślepowron, syn Remigiana, chorążego husarii wojsk litewskich bywa mylony ze swoim imiennikiem, synem Michała, łowczego sandomierskiego (zob. M. Rymszyna, Gabinet Stanisława Augusta, Warszawa 1962, s. 52) lub z podstolim nowogrodzkim (zob. I. Baranowski, Udzৃiat Stanisława Augusta i jego otoczenia w przygotowaniu Kodeksu dyplomatycznego Polski, „Przegląd Historyczny” 1911, t. 12, z. 2, s. 253).

2 J. Kossakowski, Pamiętniki Józefa Kossakonskiego biskupa inflanckiego, wyd. A. Darowski, Warszawa 1891, s. 53. 
Dzisiaj twórczość Moliwdy jest zapomniana, by nie rzec nieznana, zaś w czasach oświecenia stanisławowskiego był to jeden z czołowych twórców, należący do „przedniej straży literackiej Stanisława Augusta”’. Kossakowski był nie tylko nadwornym poetą króla, ale od 1767 roku pracował również jako sekretarz Gabinetu i zamieszkiwał w Zamku Królewskim ${ }^{4}$ W tym czasie nawiązał przyjazne relacje z Adamem Kazimierzem Czartoryskim, co zaowocowało obecnością poety na spotkaniach w Pałacu Błękitnym, a także z Adamem Naruszewiczem, który prawdopodobnie wprowadził go do grona bywalców obiadów czwartkowych, czego świadectwem są liczne utwory Kossakowskiego publikowane na łamach „Zabaw Przyjemnych i Pożytecznych", będących tubą wydawniczą uczonych spotkań. W 1775 roku Kossakowski został tłumaczem języka rosyjskiego w departamencie spraw cudzoziemskich Rady Nieustającej, zajmował się przekładem Metryki Litewskiej ${ }^{5}$.

Twórczość poetycka Kossakowskiego oscyluje wokół trzech nurtów - trzech źródeł inspiracji. Po pierwsze, Korwin jako poeta oświeceniowy uprawiał poezję okolicznościową, zarówno lekką desertową, jak i polityczną, odzwierciedlającą dramatyczne czasy stopniowej utraty niepodległości i niepewnej pozycji króla. Po drugie, tworząc w duchu wieku świateł, inspirował się poezją i kulturą antyczną. Po trzecie wreszcie, jako dworzanin Stanisława Augusta przyjmował zlecenia literackie przydzielane przez króla.

Do okolicznościowej poezji Kossakowskiego zaliczyć można jego debiut, wiersz imieninowy zadedykowany księdzu Jędrzejowi Młodziejowskiemu, późniejszemu biskupowi i kanclerzowi ${ }^{6}$, czy utwory panegiryczne dedykowane kobietom: Do Anny z. Pociejów Tyszkiewiczowej ${ }^{7}$ lub Na portret [...] Generatowej Ziem Podolskich ${ }^{8}$. Wiersze te czerpią ze swoistej oświece-

3 R. Kaleta, Bójka literacka A. Naruszewicza z. A. K. Kossakowskim, [w:] idem, Oświeceni i sentymentalni. Studia nad literatura $i$ życiem w Polsce w okeresie trzech roz̧biorów, Wrocław 1971, s. 137.

4 Ibidem.

5 E. Aleksandrowska, Antoni Korwin Kossakowski, [w:] Pisarže polskiego ośniecenia, red. T. Kostkiewiczowa, Z. Goliński, t. 1, Warszawa 1992, s. 285.

6 A. K. Kossakowski, Do Jaśnie Wielmożnego Jego Mości kesiędza Andrzeja Mtodziejowskiego Gnieźnieńskiego Kanclerza Krakowskiego Kanonika Psz̨zemskiego Archidiakona Opactwa Hebdowskiego Koadiutora Cz̨erwińskiego Administratora, w dzień ś. Andrzeja, Warszawa 1764.

7 A. K. Kossakowski, Wiersz na sprawiedliwa pochwate Heroiny W[ielkiego] Ks[iestwa] L[itewskiego] Jaśnie Wielmożnej Jej M[oś]ci Pani Anny z Pociejów Tyszkeiewiczowej Mścistanskiej Kasztelanowej, Raduńskiej Dubieckiej etc. etc. Starościny, Warszawa 1765.

8 A. K. Kossakowski, Na portret J[aśnie] O[świeconej] Księżnej J[ej] M[oś]ci, Generatowej Ziem Podolskich, „Zabawy Przyjemne i Pożyteczne” 1775, t. 10, cz. 1, s. 89-90. 
niowej mody obdarowywania znaczących osób rymami i są przykładem bardzo popularnej wówczas okolicznościowej poezji panegirycznej, która, choć z powodzeniem uprawiana przez wielu autorów, poddawana była równoczesnej krytyce jako nieszczera i mająca nikłe walory artystyczne. Dotychczasowe panegiryki zazwyczaj tworzone były w celu podtrzymywania relacji poeta-mecenas i najczęściej miały na celu zagwarantowanie jak najlepszego bytu pierwszemu przez drugiego", dlatego też były one schematyczne, przesadne i nieprzystające do rzeczywistości. Krytykowały je więc elity oświeceniowych twórców jako „płaskie podchlebstwa”, a ich autorów odsądzano od czci winnej poetom ${ }^{10}$. Początkowo krytyka ta przejawiała się w tekstach literackich, atakujących laudatorów, później została skodyfikowana również w rozprawach teoretyczno-literackich.

W rozprawach o wymowie i poezji, powstających w czasach stanisławowskich, niejednokrotnie zaznaczano, że również w obrębie właściwego poezji pochwalnej i laudacyjnej genus demonstrativum jej autorzy powinni wystrzegać się zbyt wybujałego stylu. Pisał o tym m.in. Stanisław Kostka Potocki w swej Rozprawie o sztuce pisania:

Nawet w tym rodzaju [genus demonstrativum] roztropność i umiarkowanie zachować należy, mianowicie szukać w nich rozmaitości. Zbytek ozdób ciąży nad słuchaczem i sytość w nim sprawia, a nie dość rozmaitości w ich wyborze, przywiązaną do jednostajności wzbudza tęsknotę ${ }^{11}$.

Analiza wierszy Kossakowskiego adresowanych do kobiet, mających istotny wpływ na ówczesne życie polityczne kraju, pozwala zauważyć, że

9 Por. definicję panegiryku prezentowaną przez J. W. Zawiszę, która wyznacza tego typu utworom główny cel - zaskarbienie sobie przychylności adresata, a fakultatywnie i marginalnie traktuje możliwość wpływania na odbiorców, zob. J. W. Zawisza, Panegiryczny druk okoliçnościony epoki stanisławowskiej, Wrocław 1984, s. 31.

10 Bożena Mazurkowa zaznacza jednak, że ówcześni twórcy nie tyle krytykowali okolicznościowa poezję laudacyjna jako taką, ile sposoby jej realizacji, a także skutki moralne, jakie mógł wywołać bezkrytyczny panegiryzm. Zob. B. Mazurkowa, Okoličności oraz wydaræ̌enia ¿̇ycia prywatnego i publicznego w poetyckiej dokumentacji „Zabaw Przyjemnych i Pożytecznych”, [w:] Poezja okolicznościowa w Polsce w latach 1730-1830, red. M. Nalepa, G. Trościński, R. Magryś, Rzeszów 2014, s. 212-213.

11 S. Potocki, Rozprawa o sztuce pisania, c₹yli o stylu, c₹ytana na Public₹nym Posiedzeniu Towar $y$ stwa Pr₹yjaciót Nauk dnia 7 stycznia roku 1813. Pocbwaty, mowy i rozprawy Stanisława brabi Potockiego, Senatora $i$ Wojewody, Ministra Wyznań Religijnych i Oświecenia Narodowego, Komendanta Jeneralnego Kadetów, Członka Towarzystwa Przyjaciót Nauk i Akademii Krakowskiej, Kawalera Orderów Polskich etc., cz. II, Warszawa 1816, s. 289. 
motywacją napisania tych utworów nie była pochwała płci pięknej jako takiej, ale cel dydaktyczny. Izabela Czartoryska i Anna z Pociejów Tyszkiewiczowa są jedynymi kobietami, które Moliwda obdarował wierszem. Wybór tych konkretnych adresatek zapewne nie jest przypadkowy. O ile postać księżnej Czartoryskiej jest dość znana, a jej zasługi na polu działalności społecznej, kulturalnej, a także politycznej nie podlegają dyskusji, o tyle osoba Tyszkiewiczowej na pewno wymaga przybliżenia.

Anna Pociejówna Tyszkiewiczowa (ur. 1720 lub 1725, zm. 1788), pochodziła z rodziny, w której polityka była na porządku dziennym. Jej ojciec pełnił wiele funkcji państwowych, posłował na sejmy, był senatorem w latach 1718 i 1722. Politycznie udzielali się również jej bracia Ludwik i Leonard. Prawdopodobnie do aktywnego udziału Anny w życiu politycznym zmusiła ją postawa męża Józefa, który, będąc kasztelanem mścisławskim, a później wojewodą smoleńskim, nie przykładał się do pełnionych funkcji, a nawet lekceważyl je. Wiadomo, że Tyszkiewiczowa niejednokrotnie musiała występować w imieniu męża, by ratować sprawy publiczne ${ }^{12}$.

Choć w czasach stanisławowskich coraz więcej kobiet-magnatek wkraczało do życia politycznego, to cały czas nie miały jeszcze praw obywatelskich równych mężczyznom, a ich pozycja społeczna była niższa. Dodatkowo panegiryczna przesada z zasady obecna w tego typu utworach z jednej strony jest meritum utworów pochwalnych, z drugiej zaś - wywołuje ostry sprzeciw twórców, krytyków i badaczy literatury. Wyolbrzymioną amplifikację neguje Witold Bruchnalski ${ }^{13}$. Jej negatywny wpływ na charakter utworu wskazuje również Stanisław Dąbrowski, który zauważa niebezpieczeństwo odebrania jej jako drwinę. Badacz ten zauważa, że wynika ona z braku autentycznych pozytywnych cech, które godne byłyby pochwały i wymaga uzupełnienia kreowanego (nie zaś opisywanego) wizerunku chwalonej osoby, o fikcję literacką ${ }^{14}$.

Tym bardziej wyróżnienie działalności publicznej kobiet, przejmujących nierzadko role swoich mężów, nabiera znaczenia, tłumacząc jed-

12 W. Filipczak, Anna z Pociejów Tyszkiewiczowa, wojewodzina smolenskea. Rola polityczna w crasach Rady Nieustajacej, [w:] Kobiety i wtadza w czasach dawnych, red. B. Czwojdrak, A. Kluczek, Katowice 2015, s. $409-411$.

13 W. Bruchnalski, Panegiryk, [w:] Drieje literatury pieknej w Polsce, oprac. S. Tarnowski, W. Bruchnalski, T. Sinko i in., cz. II, Kraków 1918, s. 198, 204.

14 S. Dąbrowski, Z problematyki panegiryku, ,Przegląd Humanistyczny” 1968, R. XII, nr 3, s. 45. 
nocześnie panegiryczny ton utworów. O ile jednak postawa społeczna Kossakowskiego może być postrzegana jako nowoczesna - dostrzeganie roli kobiet w społeczeństwie i ich możliwości - o tyle sposób realizacji poetyckiej obu utworów trąci barokową stylistyką i dość schematycznym pojmowaniem zarówno koncepcji panegiryku, jak i wykorzystania w poezji wątków antycznych. Oba wiersze zaczynają się pytaniem, do której z antycznych bogiń porównać można bohaterki utworów. I tak w wierszu do Czartoryskiej czytamy:

Patrz! Na złotym powozie śpieszy ku nam która

Bogini! Wszystka piękna, czy nie Cynozura? ${ }^{15}$

zaś początkowe wersy liryku poświęconego Tyszkiewiczowej brzmią:

Którym Cię z bogiń uwielbię imieniem,

Ośpiewam jakim głośnej lutni pieniem? ${ }^{16}$

Wiersz poświęcony Czartoryskiej został napisany w dużo lżejszym stylu, jest poetyckim komplementem realizującym barokową figurę sumacji, ujmującym pochwałę bohaterki dość ogólnikowo. Jedyną nieabstrakcyjną cnotą adresatki jest macierzyństwo nowego pokolenia Czartoryskich (apostrofa „matko Czartoryskich”). Wiersz ten niewatpliwie pokazuje zażyłość relacji łączących go z księstwem Generałostwem, które prawdopodobnie stały się inspiracją do napisania tego wiersza.

Wcześniejszy o dziesięć lat utwór zadedykowany Annie Tyszkiewiczowej jest ciekawym połączeniem inspiracji antycznej i dalekowschodniej. Motywy, a nawet cytaty z poezji chińskiej pojawiają się w omawianym wierszu dwukrotnie. Poeta przedstawia Kasztelanową jako kobietę mądrą, wolącą ,z Minerwą się bawić / niż morzem władać” oraz dobrą. I właśnie opisując jej dobroć, powołuje się na słowa chińskich poetów. W ósmej strofie tego wiersza czytamy:

Albo niebieskie ołtarze odarte

Odziewasz; albo wspierasz niepodparte

I tak dla nędzy gminnej krasy nieba,

(a) Obie podnosisz oczy, gdzie potrzeba $[\ldots]^{17}$.

15 A. K. Kossakowski, Na portret..., w. 1-2.

16 A. K. Kossakowski, Wiersz na sprawiedliwa pochwate Heroiny..., w. 1-2.

17 Ibidem, w. 29-32. 
Co ciekawe, fragment ten jest opatrzony przypisem autorskim (a): „Phrasis chińskich wierszopisów tak o dobroci śpiewających”.

Pięć strof dalej pojawia się kolejny dalekowschodni motyw - żółty obłok, do którego również poeta dodaje wyjaśnienie (b): „W wierszach chińskich, wzbicie się na żółty obłok wyraża doskonałość, zdolną rzecz wielką zakończyć dobrze”. I tak czytamy:

I jakim pieniem masz więc być wielbiona
Pani, tysiącem Muz niewysławiona?
Czyją myśl w górę żółty obłok wzbija (b)
Temu Cię wielbić, niechaj niebo sprzyja ${ }^{18}$.

Trudno dzisiaj dokładnie powiedzieć, jakie konkretnie utwory natchnęły Moliwdę i skąd czerpał wiedzę o motywach obecnych w poezji Chin, ale wiadomo, że w dobie stanisławowskiej moda na szeroko rozumianą orientalistykę była powszechna wśród magnaterii. Niewykluczone zatem, że mógł korzystać (zapewne z jakiegoś przekładu) poezji chińskiej, zaimportowanego na dwór Adama Kazimierza Czartoryskiego, o którym wiemy, że był miłośnikiem Wschodu, choć bardziej interesowała go Turcja czy Persja ${ }^{19}$. Być może poeta miał dostęp do jakichś źródeł poezji chińskiej, które były sprowadzane do tworzonej właśnie biblioteki Stanisława Augusta. Możliwe, że jakieś zbiory tej poezji pojawiły się w którymś z wymienionych księgozbiorów za sprawą przejeżdżającego przez Polskę w 1747 roku bibliotekarza z działu rękopisów wschodnich paryskiej Biblioteki Narodowej, który zwiedzał zbiory orientaliów Augusta Czartoryskiego ${ }^{20}$.

Wracając do antycznych źródeł inspiracji w poezji Kossakowskiego, trzeba zwrócić uwagę na monumentalną, licząca prawie 700 wersów sielankę dedykowaną Adamowi Kazimierzowi Czartoryskiemu², wzo-

18 Ibidem, w. 49-52.

19 Więcej na ten temat zob. J. Reychman, $Z$ driejów orientalizmu polskiego w dobie oświecenia, [w:] Szkice z. driejów polskiej orientalistyki, red. J. Reychman, Warszawa 1966, s. 79-102.

20 Zob. J. Reychman, Zbiory orientaliów w Polsce XVIII w., [w:] Studia nad ksiażka poświęcone pamieci Kazimierza Piekarskiego, red. K. Budzyk, A. Kawecka-Gryczowa, Wrocław 1951, s. 285-286.

21 A. K. Kossakowski, Do Jaśnie Oświeconego Ksiecia J[ego] M[oś]ci Adama Czartoryskiego, Generała Ziem Podolskich A[ntoni] Kos[sakowski], S[ekretarz] J[ego] K[rólewskiej] M[ości] Utomek, wierszón... opisujacych obraz $\dot{z} y c i a$ wiejskiego oddaje, „Zabawy Przyjemne i Pożyteczne” 1774, t. 10, cz. 1, s. $37-89$. 
rowaną na horacjańskiej epodzie Beatus ille qui procul negotis..., a także naśladującą Georgiki Wergiliusza. Jako ważne źródło inspiracji tego utworu, a przede wszystkim przesłania w nim zawartego, wskazać należy również poematy Hezjoda, głównie zaś Prace $i$ dnie. W tym utworze starożytny poeta przedstawia apologię pracy, zwłaszcza uprawy roli, co jak wiadomo nie było ówcześnie poglądem powszechnym. Zainteresowanie polskich twórców pracującymi pasterzami wpisywało się w nurt spajania polskiej magnaterii i przypisywania jej współodpowiedzialności za losy kraju. Było także próbą zjednoczenia obozu królewskiego i dworów magnackich wokół wspólnej, narodowej sprawy, co nie było łatwe, dlatego teksty pierwowzorów zostały tak przepracowane, by stanowić apologię życia na wsi, a jednocześnie być pochwała letniej rezydencji księstwa Generałostwa. Z jednej strony poeta pochlebia Czartoryskim, pokazując swoje uznanie dla ich zaangażowania, z drugiej pokazuje pozytywny wzorzec osobowy dla innych magnatów, usiłując przekonać ich do swoich racji. Zaczerpnięcie motywów z tradycji antycznej, wysoko cenionej przez stanisławowski parnas, świadczyło o podniesieniu rangi moralnej prezentowanych autorytetów, gdyż wzorce antyczne były tymi, do których chętnie dążono.

Twórczość Antoniego Korwina Kossakowskiego zawiera również elementy ,autoinspiracji”. Poeta w niektórych utworach „opowiada” wydarzenia ze swojego życia lub przywołuje wątki z własnej wcześniejszej twórczości, identyfikując się z nią. Za przykład może posłużyć omawiana wyżej sielanka Ulomek wierszów..., w której pierwsze dziesięć wersów Moliwda poświęca autoprezentacji:

Ja to ten, co przed laty gwiazd śpiewałem biegi
I czujny strzelec, jakie w kniejach ma noclegi,
I kwiatów jacynt krasa, jak świetny w Auguście,
Zadałem też cios długi swawolnej rozpuście;
Która, zebrawszy tłumy rynkowej hołoty,
Jak bydło nieporządne ciśnie się w dom cnoty;
Śpiewałem i Dafnisa, kiedy był ścigany
Od zdrajców, ten narodu pasterz ukochany!
Śpiewałem mu i rano, i wieczór, i nieraz -
Słuchaj ziemio! Wy ludzie! co zaśpiewam teraz

22 Ibidem, w. 1-10. 
W pierwszych trzech wersach cytowanego fragmentu Moliwda przywołuje swoje wcześniejsze sielanki: Jaśnie wielmożnemu Jegomości Panu Hiacyntowi Ogrodzkiemu... wiersz.pasterski... dnia 16 augusta r. 1767 i JJ. WW. Jmí PP. Kazimierzowi Karasiowi kasztelanowi wiskiemu... Jackowi Ogrodzkiemu, pisarzowi w. koronnemu... na poczatku 1771 roku 1 stycznia prośba pasterska oddana. W dalszej części poeta przypomina zaś utwór Do narodu i potomności o okropnym przypadku przę Jego Królewska Mość, P[ana] N[aszego] M[itościwego] w roku 1771 dnia 3 listopada doświadczonym [...], opisujący próbę uprowadzenia króla ze stolicy przez spiskowców konfederacji barskiej, znany ówcześnie z druków ulotnych, opublikowany w „Zabawach Przyjemnych i Pożytecznych” w szóstą rocznicę zamachu w 1777 roku. Tym samym Kossakowski, identyfikując się ze swoją wcześniejszą twórczościa, podkreśla niezmienność postawy względem obozu królewskiego i ,gabinetu” oraz gotowość do dalszych działań propagandowych na rzecz monarchy i jego wizji nowoczesnego społeczeństwa. Stanisław August, występujący tu pod postacia Dafnisa, jest pasterzem mającym przywieść lud do określonego stanu - gwarantującego mu szczęście i spokojną egzystencję, będącego wizją polityczną obozu królewskiego.

Innym przykładem inspiracji, tym razem można by ją nazwać ,inspiracją zewnętrzną", jest działalność literacka - translatorska, narzucona poniekąd przez króla. Kossakowski, jak wspomniano, w królewskim gabinecie pełnił funkcję tłumacza z języka rosyjskiego. Był także doskonale obeznany z tamtejszą kulturą i topografia. Pewnie dlatego Stanisław August polecił mu przetłumaczenie komedii Oszukaniec (Obmanszczik) autorstwa carycy Katarzyny II. Komedia ta wystawiona została w Petersburgu w styczniu 1786 roku. Tytułowym oszustem jest Alessandro di Cagliostro (właśc. Giuseppe Balsamo), znany wówczas niemal w całej Europie wyłudzacz pieniędzy, klejnotów, a także domniemany alchemik i uzdrowiciel. Swoje „niezwykłe moce” zdołał zaprezentować także w Warszawie w 1780 roku, gdzie powołał do życia coś na kształt loży wolnomularskiej, zwanej lożą egipską ${ }^{23}$.

Oryginał Obmanszczikea zaprezentowano na petersburskich deskach w styczniu, a zaraz potem Stanisław August otrzymał od swego przed-

23 A. Moszyński, Cagliostro zdemaskowany w Warszawie, „Ars Regia” 1997, nr 6/1-2, s. 85, zob. także Z. Raszewski, Oszust, [w:] idem, Starośmiecczyzna i postęp czasu. O teatrze polskim 1765-1865, Warszawa 1963, s. 65-71.

Małgorzata Pawlata · Inspiracje twórcze Antoniego Korwina Kossakowskiego 
stawiciela dyplomatycznego, Augusta Debolego, przekład sztuki, który jednak mu się nie spodobał ${ }^{24}$. W tym przypadku polecił obeznanemu z językiem i kulturą Rosji Kossakowskiemu sporządzenie nowego. Lojalny Moliwda, rzecz jasna, zadanie wykonał, ale jego przekładu nie można ocenić jako bardziej udanego od dzieła Debolego. Warszawska premiera Obmanszrziłka odbyła się już 23 kwietnia 1786 roku, jednak dokładnie nie wiadomo, czyj przekład ostatecznie został zaprezentowany na scenie, choć jest więcej niż prawdopodobne, że nie była to adaptacja Kossakowskiego ${ }^{25}$. Praca nad „przystosowaniem” dzieła carycy Katarzyny II była ostatnim zajęciem literackim Moliwdy, ponieważ w tym samym roku około świąt Bożego Narodzenia Kossakowki zachorował i zmarł 29 grudnia 1786 roku.

W twórczości Antoniego Korwina można zatem wyodrębnić kilka źródeł inspiracji, zależnych od okoliczności, w których znajdował się poeta. Jednak wszystkie one w jakimś sensie wiążą się ze stanowiskiem zajmowanym przez Moliwdę w gabinecie Stanisława Augusta, a już na pewno ściśle wynikają z jego pracy na rzecz propagowania działalności monarchy, nie tylko w kwestiach politycznych, lecz także lobbowanych przez króla przedsięwzięciach kulturalnych, a nawet osobistych.

\section{Bibliografia}

Aleksandrowska E., Antoni Korwin Kossakowski, [w:] Pisarze polskiego oświecenia, red. T. Kostkiewiczowa, Z. Goliński, t. 1, Warszawa 1992, s. 284-285.

Baranowski I., Udziat Stanistawa Augusta i jego otoczenia w przygotowaniu Kodeksu dyplomatycznego Polski, „Przegląd Historyczny” 1911, t. 12, z. 2, s. 251-256. Bruchnalski W., Panegiryk, [w:] Drieje literatury pieknej w Polsce, oprac. S. Tarnowski, W. Bruchnalski, T. Sinko i in., cz. II, Kraków 1918, s. 198-208.

Dąbrowski S., Z problematyki panegirykeu, „Przegląd Humanistyczny” 1968, R. XII, nr 3, s. 43-55.

Filipczak W., Anna z. Pociejów Tyszkiewiczowa, wojewodżina smoleńska. Rola politycrna w crasach Rady Nieustajacej, [w:] Kobiety i władra w czasach dawnych, red. B. Czwojdrak, A. Kluczek, Katowice 2015, s. 405-434.

24 Z. Raszewski, Kto przettumaczyt „Osそusta”?, „Pamiętnik Literacki” 1964, nr 55/2, s. 202-205.

25 Ibidem. 
Kaleta R., Bójka literacka A. Naruszewicza z. A. K. Kossakowskim, [w:] idem, Oswieceni $i$ sentymentalni. Studia nad literatura $i$ zyciem w Polsce w okresie trzech rozbiorów, Wrocław 1971, s. 137-168.

Kossakowski A. K., Do Jaśnie Oświeconego Księcia J[ego] M[oś]ci Adama Czartoryskiego, Generała Ziem Podolskich A[ntoni] Kos[sakowski], S[ekretarz] J[ego] K[rólewskiej] M[ósci] Utomek wierszón... opisujacych obraz życia wiejskiego oddaje, „Zabawy Przyjemne i Pożyteczne” 1774, t. 10, cz. 1, s. 37-89.

Kossakowski A. K., Do Jaśnie Wielmożnego Jego Mości księdza Andrzeja Mtodriejowskiego Gnieźnieńskiego Kanclerz̨a Krakowskiego Kanonika Pszrzenskiego Archidiakona Opactwa Hebdowskiego Koadiutora Czerwińskiego Administratora, w dzień s. Andræeja, Warszawa 1764.

Kossakowski A. K., Na portret J[á́nie] O[śmieconej] Księznej J[ej] M[oś]ci, Generatowej Ziem Podolskich, „Zabawy Przyjemne i Pożyteczne” 1775, t. 10, cz. 1, s. 89-90.

Kossakowski A. K., Wiersz na sprawiedliwa pochwate Heroiny W[ielkiego] Ks [iestwa] L[itewskiego] Jaśnie Wielmożnej Jej M[oś]ci Pani Anny z Pociejón Tysžkiewiczowej Mścisławskiej Kasztelanowej, Radunskkiej Dubieckiej etc. etc. Starościny, Warszawa 1765.

Kossakowski J., Pamiętniki Józefa Kossakowskiego biskupa inflanckiego, wyd. A. Darowski, Warszawa 1891.

Mazurkowa B., Okoliczności oraz uydarzenia życia prywatnego i publicznego w poetyckiej dokumentacji „Zabaw Przyjemnych i Pożytecznych”, [w:] Poezja okolicznościowa w Polsce w latach 1730-1830, red. M. Nalepa, G. Trościński, R. Magryś, Rzeszów 2014, s. 211-251.

Moszyński A., Cagliostro zdemaskowany w Warszawie, „Ars Regia” 1997, nr 6/1-2.

Potocki S., Rozprawa o sztuce pisania, czyli o stylu, czytana na Publicznym Posiedženiu Towarzystwa Przyjaciót Nauk dnia 7 stycznia roku 1813. Pochwaly, mowy i rozprawy Stanistawa hrabi Potockiego, Senatora $i$ Wojewody, Ministra Wyznań Religijnych i Oswiecenia Narodowego, Komendanta Jeneralnego Kadetów, Członka Towarzystwa Przyjaciót Nank i Akademii Krakonskiej, Kawalera Orderów Polskich etc., cz. II, Warszawa 1816.

Raszewski Z., Kto przettumaczyt „Oszusta”?, „Pamiętnik Literacki” 1964, nr 55/2, s. 202-205.

Raszewski Z., Oszust, [w:] idem, Staroświecczyzna i postęp czasu. O teatrzepolskim 1765-1865, Warszawa 1963, s. 65-95. 
Reychman J., Zbiory orientaliów w Polsce XVIII w., [w:] Studia nad ksiażkapośmiecone pamieci Kazimierza Piekarskiego, red. K. Budzyk, A. Kawecka-Gryczowa, Wrocław 1951, s. 283-294.

Reychman J., Z driejów orientaližmu polskiego w dobie oświecenia, [w:] Sžice z džiejów polskiej orientalistyki, red. J. Reychman, Warszawa 1966, s. 79-105.

Rymszyna M., Gabinet Stanistawa Augusta, Warszawa 1962.

Zawisza J., Panegiryczny druk okolicznościony epoki stanisławowskiej, Wrocław 1984.

\section{Źródła inspiracji twórçości Antoniego Korwina Kossakowskiego}

Antoni Korwin Kossakowski to ciekawa, choć zapomniana postać polskiego panteonu literackiego doby stanisławowskiej. Człowiek o nietuzinkowej biografii, sekretarz króla, tłumacz języka tureckiego i rosyjskiego, twórca poezji okolicznościowej i politycznej. Poeta inspirujący się codziennymi sprawami upadającego kraju, tworzący patriotyczne ody i sielanki, przedstawiający rodzima rzeczywistość z elementami antycznego folkloru. Autor tekstów o bardzo różnorodnej tematyce - od poezji religijnej po suplement do przewodnika po stołecznych domach rozkoszy. Z inspiracji króla Stanisława Augusta autor przekładu komedii Oszukaniec napisanej przez carycę Katarzynę II.

\section{Antoni Korwin Kossakowski's sources of inspiration in bis writing}

Antoni Korwin Kossakowski is an interesting and forgotten figure of Polish literature from the times of King Stanisław August Poniatowski. He had an exceptional life. He was the King's secretary, a translator of Turkish and Russian, he wrote political and occasional poetry. He drew inspiration from everyday life in the country on the verge of downfall. He wrote patriotic odes and bucolics depicting familiar reality with elements of antique folklore. He wrote on variety of subjects ranging from religious poetry to the supplement to the guide of houses of pleasure in the capital city. From the King's inspiration, he also translated into Polish a comedy The Cheater wrote by tsarina Catharina II. 